\title{
To Study the Effect of Ketamine Gargle for Attenuating Post Operative Sore Throat, Cough and Hoarseness of Voice
}

\author{
Jaya Lalwani, Rashmi Thakur, Manju Tandon and Sandeep Bhagat* \\ Department of anaesthesiology and critical care, Pt. Jawahar Lal Nehru Medical College, India
}

Submission: October 14, 2017; Published: November 27, 2017

*Corresponding author: Sandeep Bhagat, Department of anaesthesiology and critical care, Pt. Jawahar Lal Nehru Medical College, Raipur, Chhattisgarh, India, Email: sandeepbhagat642@gmail.com

\begin{abstract}
Objective: To study the effect of ketamine gargle in reduction of postoperative sore throat (POST), hoarseness of voice and cough following endotracheal intubation.

Materials and Methods: Two hundred patients aged between 15-50 years with American Society of Anaesthesiologists I and II, undergoing elective surgical procedures performed under general anaesthesia were randomly divided into two groups of 100 patients in each. Group C received $30 \mathrm{ml}$ of normal saline and Group K received $50 \mathrm{mg}(1 \mathrm{ml})$ of Ketamine in $29 \mathrm{ml}$ of normal saline. All the patients were asked to gargle with the preparation for $30 \mathrm{sec}$ after their arrival in the operation room $5 \mathrm{~min}$ before induction of anaesthesia. On arrival in the post operative ward 0 hour, at 2 hour, at 4 hour and at 24 hour thereafter, the patients were questioned by a blinded investigator whether he/she had experienced sore throat, hoarseness or cough. POST, hoarseness and cough was graded on a four point scale.
\end{abstract}

Results: The incidence of POST was higher in C group compared with K group at 0 hour, 2 hour, 4 hour and 24 hour after extubation.

Conclusion: In conclusion, gargling with ketamine decreases the incidence and severity of POST, hoarseness of voice and cough.

Keywords: Endotracheal Intubation; Ketamine; Postoperative Sore Throat

\section{Introduction}

Maintaining airway in an anaesthetized patient is of vital importance and securing the airway with endotracheal tube has an advantage of intermittent positive pressure ventilation with minimal risk of aspiration [1]. Almost all patients who are given general anaesthesia, undergo endotracheal intubation either for long duration or short duration surgery resulting in injury to airway mucosa or vocal cords which may be the cause of post operative sore throat [2,3]. Postoperative sore throat (POST) has been ranked by American anesthesiologists as the eighth most important problem of current clinical anaesthesiology [3,4]. The reported incidence of post operative sore throat varies from $21 \%$ to $65 \%$ [5-8]. Hoarseness of voice (HOV) has also been reported with incidences varying between $4 \%$ to $42 \%$ [9].

Numerous non-pharmacological and pharmacological trails have been used for attenuating POST, HOV and cough with variable success [10]. The ionotropic glutamate receptors N-methyl-Daspartate (NMDA), alpha-amino-3-hydroxyl-5-methyl-4-isoxazolepropionic acid and kainate receptors are found in the central nervous system as well as the peripheral nerves [11]. Behavioural studies indicated that activation of these receptors result in nociceptive behaviours and contribute to inflammatory pain $[11,12]$. Moreover, experimental studies showed that peripherally administered NMDA receptor antagonists are involved with antinociception and anti-inflammatory cascade $[11,13,14]$.

NMDA-receptor antagonists act at different levels of inflammation, interacting with inflammatory cells recruitment, cytokines production, and inflammatory mediator regulation. The resultant effect of these interactions confers that ketamine has an anti-proinflammatory effect by limiting exacerbation of systemic inflammation without affecting local healing processes $[13,14]$. In this study, we have evaluated whether prophylactic Ketamine gargle reduces POST, hoarseness of voice and cough after endotracheal intubation and compared with placebo using normal saline group(C). Ketamine is easily available and a gargle may be a simple, cost-effective method to decrease POST symptoms. 


\section{Methods}

After approval from institutional ethics committee, study was conducted in the Department of Anaesthesiology and Critical Care, Pt. J.N.M. Medical College and Dr.B.R.A.M. Hospital, Raipur (C.G) from 2014-2016. The study was conducted in a prospective, randomized, placebo-controlled and single blinded manner. Patients of either sex aged between 15 to 50 years, ASA I - II, undergoing elective surgical procedures of half hour to three hour duration surgeries were included in the study. Patients with history of prior sore throat, patients with known upper respiratory tract infection or lower respiratory tract infection, allergies to NSAID medication, patients undergoing oropharyngeal, laryngeal or ear surgeries and requiring more than two attempts at intubation were excluded from this study.

Written informed consent was obtained from all the patients who fulfilled the inclusion criteria and were willing to participate in the study. Before the study, a power of study was calculated by using software G Power 3.0.10, taking the incidence of POST from the study of Canbay et al. [15] and considering a probability level of 0.05 ( $\alpha$ - error) and power of $0.80(1-\beta)$ yielded a sample size of 100 patients in each group. Patients were randomly allocated into two groups of 100 patients in each group: Group (K): ketamine 50 $\mathrm{mg}$ in $29 \mathrm{ml}$ normal saline. Group (C): $30 \mathrm{ml}$ normal saline

After shifting patient to the operating room, intravenous access was obtained on the forearm with 18G IV cannula and appropriate fluid was started. Patients were monitored for heart rate, noninvasive blood pressure, SpO2 in Philips MP30 monitor. Patients were randomized into the two groups with the help of a computer-generated table of random numbers. All patients were made to gargle with the mixture according to assigned groups for 30 seconds, 5 minutes before induction. Premedication was done with intravenous inj. Ranitidine $1 \mathrm{mg} / \mathrm{kg}$, inj. Ondansetron $0.1 \mathrm{mg} /$ $\mathrm{kg}$, inj.Glycopyrolate $0.01 \mathrm{mg} / \mathrm{kg}$, inj.Midazolam $0.05 \mathrm{mg} / \mathrm{kg}$ and inj. Pentazocine $0.5 \mathrm{mg} / \mathrm{kg}$. Induction was done with intravenous inj .Propofol $2 \mathrm{mg} / \mathrm{kg}$ and Inj. Succinylcholine $2 \mathrm{mg} / \mathrm{kg}$. Trachea was intubated with a soft seal cuffed sterile poly vinyl chloride endotracheal tube (sterimed medical device) of size $8-8.5 \mathrm{~mm}$ internal diameter in males and $7-7.5 \mathrm{~mm}$ internal diameter in females. Endotracheal tube cuff was filled until no audible leak is heard with a peak airway pressure at $20 \mathrm{~cm} \mathrm{H} 20$.

Anaesthesia was maintained on Isoflurane, $02+$ N02 [40-60]\% mixture and i.v. Atracurium $0.25 \mathrm{mg} / \mathrm{kg}$ bolus and then $0.1 \mathrm{mg} / \mathrm{kg}$ maintenance doses were given at 20 minutes intervals [3]. At the end of surgery, all the inhalational agents were stopped and $100 \%$ oxygen was administered. Neuromuscular blockade was reversed by i.v. Neostigmine $0.05 \mathrm{mg} / \mathrm{kg}$ and i.v. Glycopyrrolate $0.1 \mathrm{mg} / \mathrm{kg}$. Suction was done using 12 gauge catheters under direct vision via gentle laryngoscopy so as to avoid trauma to the oropharynx. Patients were extubated when fully awake and conscious after deflating the cuff. Patients were turned to prop up position and were given oxygen via facemask and shifted to postoperative ward.
Patients were assessed at 0, 2, 4 and 24 hours post extubation for incidences of sore throat, hoarseness of voice and cough by a blinded investigator.

Assessment was made as per the four point scale grading system. POST was graded: 0 , no sore throat; 1 , mild (less than what is seen in common cold); 2 , moderate (like what is seen in common cold); 3 , Severe (more than what is seen in common cold). HOV was graded: 0 , no hoarseness; 1 , mild (no hoarseness at the time of interview but had it previously); 2 , moderate (only is felt by the patient at the time of interview); 3 , severe (recognizable at the time of interview). Cough was graded: 0 , no cough; 1 , mild (less than what is seen in common cold); 2 , moderate (like what is seen in common cold); 3 , Severe (more than what is seen in common cold). The statistical analysis was performed using unpaired t-test. The results were considered significant statistically, if $\mathrm{P}$ value was less than 0.05 were assessed at $0,2,4$ and 24 hours post extubation for incidences of sore throat, hoarseness of voice and cough by a blinded investigator.

Assessment was made as per the four point scale grading system. POST was graded: 0 , no sore throat; 1 , mild (less than what is seen in common cold); 2 , moderate (like what is seen in common cold); 3 , Severe (more than what is seen in common cold). HOV was graded: 0 , no hoarseness; 1 , mild (no hoarseness at the time of interview but had it previously); 2 , moderate (only is felt by the patient at the time of interview); 3 , severe (recognizable at the time of interview). Cough was graded: 0 , no cough; 1 , mild (less than what is seen in common cold); 2 , moderate (like what is seen in common cold); 3 , Severe (more than what is seen in common cold). The statistical analyses were performed using unpaired t-test. The results were considered significant statistically, if $\mathrm{P}$ value was less than 0.05 .

\section{Results}

Table 1: Demographic Profile.

\begin{tabular}{|c|c|c|c|}
\hline & $\begin{array}{c}\text { Group } \\
\mathbf{C - ( n = 1 0 0 )}\end{array}$ & $\begin{array}{c}\text { Group- } \\
\mathbf{K}(\mathbf{n = 1 0 0})\end{array}$ & P-value \\
\hline $\begin{array}{c}\text { Male: Female } \\
(\mathrm{n})\end{array}$ & $56: 44: 00$ & $50: 50: 00$ & NS \\
\hline Age (yr) & $35.62 \pm 8.71$ & $32.74 \pm 8.68$ & NS \\
\hline Weight (kg) & $52.6 \pm 9.84$ & $51.2 \pm 8.23$ & NS \\
\hline $\begin{array}{c}\text { Duration of } \\
\text { surgery (min) }\end{array}$ & $114.7 \pm 31.5$ & $114.4 \pm 29.9$ & NS \\
\hline
\end{tabular}

There were no significant differences between both the groups in terms of age, bodyweight, gender distribution or duration of anaesthesia (Table 1). There were no severe complications in either group. The incidence of sore throat at last $24 \mathrm{~h}$ was $56 \%$ in group C compared to $20 \%$ in group K (Table 2). This difference in development of sore throat between the two groups was found to be statistically significant $(\mathrm{P}<0.001)$. Significantly more patients suffered severe POST in Group C at 4 and $24 \mathrm{~h}$ compared with Group K. Table 3 shows incidence of hoarseness at $0 \mathrm{~h}, 2 \mathrm{~h}, 4 \mathrm{~h}$, and 


\section{Journal of Anesthesia \& Intensive Care Medicine}

24h was higher in group C compared to group K. Similarly Table group C compared to group K. No local or systemic side effects 4 shows incidence of cough at $0 \mathrm{~h}, 2 \mathrm{~h}, 4 \mathrm{~h}$, and $24 \mathrm{~h}$ was higher in were observed between both the groups.

Table 2: Comparison of severity of POST at $0,2,4$ and $24 \mathrm{~h}$.

\begin{tabular}{|c|c|c|c|c|c|c|c|c|}
\hline \multirow[b]{2}{*}{$\begin{array}{l}\text { Grade of } \\
\text { Sore Throat }\end{array}$} & \multicolumn{2}{|c|}{0 hour } & \multicolumn{2}{|c|}{2 hour } & \multicolumn{2}{|c|}{4 hour } & \multicolumn{2}{|c|}{24 hour } \\
\hline & $\mathbf{K}$ & C & $\mathbf{K}$ & C & $\mathbf{K}$ & C & $\mathbf{K}$ & C \\
\hline No & $57 \%$ & $22 \%$ & $62 \%$ & $28 \%$ & $75 \%$ & $40 \%$ & $80 \%$ & $44 \%$ \\
\hline Mild & $33 \%$ & $45 \%$ & $30 \%$ & $40 \%$ & $21 \%$ & $14 \%$ & $14 \%$ & $6 \%$ \\
\hline Moderate & $7 \%$ & $20 \%$ & $5 \%$ & $10 \%$ & $4 \%$ & $18 \%$ & $6 \%$ & $16 \%$ \\
\hline Severe & $3 \%$ & $13 \%$ & $3 \%$ & $22 \%$ & 0 & $28 \%$ & 0 & $34 \%$ \\
\hline $\begin{array}{l}\text { Total pt } \\
\text { having sore } \\
\text { throat }\end{array}$ & $43 \%$ & $78 \%$ & $38 \%$ & $72 \%$ & $25 \%$ & $60 \%$ & $20 \%$ & $56 \%$ \\
\hline P value & \multicolumn{2}{|c|}{0.001} & \multicolumn{2}{|c|}{0.001} & \multicolumn{2}{|c|}{0.0001} & \multicolumn{2}{|c|}{0.0001} \\
\hline
\end{tabular}

Data are presented as percentage (\%) of patients.

Table 3: Comparison of severity of HOV at 0, 2, 4 and 24h. Data are presented as percentage (\%) of patients.

\begin{tabular}{|c|c|c|c|c|c|c|c|c|}
\hline \multirow[b]{2}{*}{$\begin{array}{l}\text { Grade of } \\
\text { Hoarseness }\end{array}$} & \multicolumn{2}{|c|}{0 hour } & \multicolumn{2}{|c|}{2 hour } & \multicolumn{2}{|c|}{4 hour } & \multicolumn{2}{|c|}{24 hour } \\
\hline & $(\mathrm{K})$ & (C) & $(\mathrm{K})$ & (C) & $(\mathrm{K})$ & (C) & $(\mathrm{K})$ & (C) \\
\hline No & $64 \%$ & $39 \%$ & $72 \%$ & $32 \%$ & $75 \%$ & $40 \%$ & $82 \%$ & $46 \%$ \\
\hline Mild & $25 \%$ & $37 \%$ & $20 \%$ & $33 \%$ & $19 \%$ & $17 \%$ & $16 \%$ & $7 \%$ \\
\hline Moderate & $8 \%$ & $15 \%$ & $5 \%$ & $17 \%$ & $4 \%$ & $19 \%$ & $2 \%$ & $14 \%$ \\
\hline Severe & $3 \%$ & $9 \%$ & $3 \%$ & $18 \%$ & $2 \%$ & $24 \%$ & 0 & $33 \%$ \\
\hline $\begin{array}{c}\text { Total pt } \\
\text { having } \\
\text { hoarseness }\end{array}$ & $36 \%$ & $61 \%$ & $28 \%$ & $68 \%$ & $25 \%$ & $60 \%$ & $18 \%$ & $54 \%$ \\
\hline P value & \multicolumn{2}{|c|}{0.01} & \multicolumn{2}{|c|}{0.0001} & \multicolumn{2}{|c|}{0.0001} & \multicolumn{2}{|c|}{0.0001} \\
\hline
\end{tabular}

Table 4: Comparison of severity of cough at 0, 2, 4 and $24 \mathrm{~h}$. Data are presented as percentage (\%) of patients

\begin{tabular}{|c|c|c|c|c|c|c|c|c|}
\hline \multirow[b]{2}{*}{$\begin{array}{l}\text { Grade of } \\
\text { Cough }\end{array}$} & \multicolumn{2}{|c|}{0 hour } & \multicolumn{2}{|c|}{2 hour } & \multicolumn{2}{|c|}{4 hour } & \multicolumn{2}{|c|}{24 hour } \\
\hline & $(\mathrm{K})$ & (C) & $(\mathrm{K})$ & (C) & (K) & (C) & $(\mathrm{K})$ & (C) \\
\hline No & $68 \%$ & $31 \%$ & $72 \%$ & $35 \%$ & $80 \%$ & $42 \%$ & $85 \%$ & $49 \%$ \\
\hline Mild & $25 \%$ & $40 \%$ & $20 \%$ & $30 \%$ & $15 \%$ & $19 \%$ & $11 \%$ & $7 \%$ \\
\hline Moderate & $5 \%$ & $18 \%$ & $6 \%$ & $15 \%$ & $5 \%$ & $17 \%$ & $4 \%$ & $13 \%$ \\
\hline Severe & $2 \%$ & $11 \%$ & $2 \%$ & $20 \%$ & 0 & $22 \%$ & 0 & $31 \%$ \\
\hline $\begin{array}{c}\text { Total pt } \\
\text { having cough }\end{array}$ & $32 \%$ & $69 \%$ & $28 \%$ & $65 \%$ & $20 \%$ & $58 \%$ & $15 \%$ & $51 \%$ \\
\hline$P$ value & \multicolumn{2}{|c|}{0.0002} & \multicolumn{2}{|c|}{0.0001} & \multicolumn{2}{|c|}{0.0001} & \multicolumn{2}{|c|}{0.0001} \\
\hline
\end{tabular}

\section{Discussion}

Generally, POST is resolved spontaneously without specific treatment however, many patients complain of POST after general anesthesia with endotracheal intubation. We found that the incidence and severity of POST were reduced after preoperative gargling with ketamine compared with saline gargling in patients undergoing general anaesthesia with endotracheal intubation for up to $24 \mathrm{~h}$. Incidence of POST in various studies done previously varied from $56.6 \%$ - 74\% in group C and from $30 \%$ - 40\% in group $\mathrm{K}$ in Canbay et al. [15]. Similarly the incidence of POST in various studies varied from $46.7 \%$ - 90\% in group C and from $13.3 \%$ $40 \%$ Rudra A et al. [8], Shrestha SK et al. [16], Tejashwini et al. [17].

In our study the incidence of hoarseness at $0 \mathrm{~h}, 2 \mathrm{~h}, 4 \mathrm{~h}$, and $24 \mathrm{~h}$ was $61 \%, 68 \%, 60 \%$, and $54 \%$ in C group compared to $36 \%, 28 \%$, $25 \%$, and $18 \%$ in $\mathrm{K}$ group. Rajkumar G et al. [10] in their study observed decrease incidence of hoarseness of voice in group $\mathrm{K}$ compared to group C at 0, 2, 4 and 24 hours. Kamble NP et al. [18] in their study, no patients complained of hoarseness of voice in group K compared to group C. Sore throat related to endotracheal 
tube might be consequence of localized trauma, leading to aseptic inflammation of pharyngeal mucosa. It may also be associated with edema, congestion, and pain. Reduction of this inflammation by ketamine gargling may be the reason for decrease in the incidence and severity of POST in our study.

\section{Conclusion}

We found that preoperative gargling with ketamine was effective in decreasing incidences and severity of postoperative sore throat, hoarseness of voice and cough as compared to normal saline, upto $24 \mathrm{hr}$ post extubation. In current scenario ketamine is a simple and effective best possible way to control postoperative sore throat, hoarseness of voice and cough in patients undergoing general anaesthesia with endotracheal intubation.

\section{Referencces}

1. Kazemi A, Amini A (2007) The effect of betamethasone gel in reducing sore throat, cough, and hoarseness after laryngo-tracheal intubation. Middle East J Anesthesiol 19(1): 197-204.

2. Loeser EA, Bennett GM, Orr DL, Stanley TH (1980) Reduction of postoperative sore throat with new endotracheal tube cuffs. Anaesthesiology 52(3): 257-259.

3. Hohlrieder M, Tiefenthaler W, Klaus H, Gabl M, Kavakebi P, et al. (2007) Effect of total intravenous anaesthesia and balanced anaesthesia on the frequency of coughing during emergence from the anaesthesia. $\mathrm{Br}$ J Anaesth 99 (4): 587-591.

4. Rabbani MW, Yousaf M, Bushra (2015) Comparison of Ketamine Gargles with Placebo for reducing Postoperative Sore throat. Pakistan Journal of Medicine and Health Sciences 9(2): 748-751.

5. Ali AA, Mudassa RA, Ali SA, Shahzad S (2013) Comparison of frequency of postoperative sore throat, cough and hoarseness of voice with and without betamethasone gel application on endotracheal tube. Pakistan Journal of Medicine and Health Sciences 7: 820-824.

6. Doukumo D, Faponle A, Bolaji B, Adenekan A, Olateju S (2011) Effects of lidocaine and k-y jellies on sore throat, cough, and hoarseness following endotracheal anaesthesia. J West Afr Coll Surg 1(3): 44-61.
7. Loix S, De Kock M, Henin P (2011) The anti-inflammatory effects of ketamine: state of the art. Acta Anaesthesiol Belg 62(1): 47-58.

8. Rudra A, Ray S, Chatterjee S, Ahmed A, Ghosh S (2009) Gargling with Ketamine Attenuates the Postoperative Sore Throat. Indian Journal of Anaesthesia 53 (1): 40-43

9. Jensen PJ, Hommelgaard P, Sondergaard P, Eriksen S (1982) Sore throat after operation: Influence of tracheal intubation, intracuff pressure and type of cuff. Br J Anaesth 54(4): 453-456.

10. Rajkumar G, Eshwori L, Konyak PY, Singh LD, Singh TR, et al. (2012) Prophylactic ketamine gargle to reduce post-operative sore throat following endotracheal intubation. Journal of Medical Society 26(3): 175-179.

11. Carlton SM, Zhou S, Coggeshall RE (1998) Evidence for the interaction of glutamet and NK1 receptors in the periphery. Brain Res 790(1-2): 160-169.

12. Carlton SM, Coggeshall RE (1999) Inflammation-induced changes in peripheral glutamate receptor populations. Brain Res 820(1-2): 63-70.

13. Oatway M, Reid A, Sawynok J (2003) Peripheral antihyperalgesic and analgesic actions of ketamine and amitriptyline in a model of mild thermal injury in the rat. Anesth Analg 97(1): 168-173.

14. Romero TR, Galdino GS, Silva GC, Resende LC, Perez AC, et al. (2011) Ketamine activates the L-arginine/nitric oxide/cyclic guanosine mono-phosphate pathway to induce peripheral antinociception in rats. Anesth Analg 113(5): 1254-1259.

15. Canbay O, Celebi N, Sahin A, Celiker V, Ozgen S, et al. (2008) Ketamine gargle for attenuating postoperative sore throat. Br J Anaesth 100(4): 490493.

16. Shrestha SK, Bhattarai B, Singh J (2010) Ketamine gargling and Postoperative sore throat. JNMA J Nepal Med Assoc 50(180): 282-285.

17. Tejashwini, Jagadish MB (2014) Gargling with Ketamine Attenuates Post-operative Sore Throat. Journal of Evolution of Medical and Dental Sciences 3(62): 13632-13636.

18. Kamble NP, Gajbhare MN (2015) Efficacy of Ketamine Gargles in the Prevalence of Postoperative Sore Throat after Endotracheal Intubation. Indian Journal of Clinical Anaesthesia 2(4): 251-255.

Your next submission with Juniper Publishers
will reach you the below assets
- Quality Editorial service
- Swift Peer Review
- Reprints availability
- E-prints Service
- Manuscript Podcast for convenient understanding
- Global attainment for your research
- Manuscript accessibility in different formats
( Pdf, E-pub, Full Text, Audio)
- Unceasing customer service
Track the below URL for one-step submission
https://juniperpublishers.com/online-submission.php

